UDC $342 / 9$

DOI https://doi.org/10.32849/2663-5313/2021.8.09

Petro Mozolevskyi,

PhD in Law, Assistant Consultant to the People's Deputy of Ukraine, 1, Solomianska square, Kyiv, Ukraine, postal code 03035, o.s.tarasenko@gmail.com, Petromozolevskyi@ukr.net

ORCID: orcid.org/0000-0002-3524-8868

Mozolevskyi, Petro (2021). Procedure for applying incentives to local self-government employees. Entrepreneurship, Economy and Law, 8, 59-64.

\title{
PROCEDURE FOR APPLYING INCENTIVES TO LOCAL SELF-GOVERNMENT EMPLOYEES
}

Abstract. The purpose of the article is to describe the procedure for applying incentives to the employees of local self-government bodies and identify the shortcomings of the procedure. Results. A managerial decision is defined as the professional performance of the authorized person aimed at ensuring the efficient functioning of the managed system. We argue that the procedure for applying incentives to local self-government employees is directly related to the consistency of making certain managerial decisions. It is underlined that the main indicators (conditions) for awarding bonuses to the employees of the Village Council apparatus are: 1) the implementation of the activities envisaged in the Office's work plans; 2) rational and efficient organization of the work of the team and conscientious performance of the job responsibilities; 3) effective managerial decisions, high performance; 4) timeliness and quality of preparation of background and analytical materials for draft legal regulations for consideration at sessions and meetings; 5) closer cooperation with the public, the relevant services of the district, the village, enterprises and entrepreneurs; 6) timely and effective execution of the orders, recommendations of the highest authorities, tasks and commissions assigned by the leadership of the village council; 7) creativity, initiative, professionalism and application of effective working methods; 8) quality and timely preparation of documents; 9) quality and effective processing of citizens' letters and appeals; 10) additional time worked; 11) performance of duties that are not part of the post in accordance with the job description; 12) constant self-improvement, professional development; 13) proper maintenance of the workplace, preservation of the property of the village council and its rational and careful use; 14) compliance with labour legislation, labour regulations, labour and financial discipline, occupational safety and health and fire safety. Conclusions. Therefore, the procedure for applying incentives to employees of local self-government bodies has been rather superficially regulated, and the corresponding regulatory provisions are scattered in numerous legal regulations of different legal force, that in turn leads to ambiguous interpretations. The shortcomings of this procedure include: a) the absence of clear criteria to be taken into account in determining who should be rewarded; b) the insufficiently regulated procedure for formation and issuance of the Incentive Order, its content and structure; c) the unregulated issue of supervising and control the implementation of managerial decisions related to applying incentives to local self-government employees.

Key words: management, control, function, implementation, documentation, indicators.

\section{Introduction}

A clear procedure for applying the incentives to local self-government employees is important in order to ensure that they are used in accordance with the principles of legality and fairness. Moreover, legal literature defines the concept of "procedure" as a certain sequence of actions. V.O. Navrotskyi argues that the procedure is a correct, well-arranged state, the location of something; the state at which everything goes as it should be; when nothing acts wrong, the regime of something. Further, the author reveals the social relations, which arise towards management, through naming their structural elements (Navrotskyi, 2011).
The aim of the article is to describe the procedure for applying incentives to employees of local self-government bodies and identify the shortcomings of the procedure.

2. Application of incentives to employees of local self-government bodies

Therefore, the review of the above-mentioned scientific positions establishes that the procedure is a clearly determined sequence of actions defined by law, which must be performed by authorized persons for the lawful and rational application of incentives to employees of local self-government bodies. Thus, it should be noted that the application of incentives is directly related to manage- 
rial decision-making. A managerial decision is the initial and main point in the organization of the activities of each manager. Consequently, the managerial decision can be considered as the core of the managerial process and an important tool for a systematic approach to the managed object. Each enterprise is not only a manufacturer of products but also an integral part of society. Therefore, managerial decision-making must take into account not only the economic aspect of the activity but also the totality of social, ideological, moral and other relations (Ruliev, Hutkevych, 2011).

According to Ye.Yu. Petrunia, the concept of "managerial decision" must be distinguished from "decision" in general. A person makes a lot of decisions during the life: in production, in purchasing goods, in personal relationships, etc., but they are not all managerial. The author argues that the managerial decision is characterized by: objectives (the manager does not make decisions on the basis of own needs, but rather on the basis of the problems of the particular organization); impacts (decisions made by a high-ranking manager can have a significant impact on the state of the managed object); the division of labour (there is a division of labour within the organization: some workers are engaged in problem analysis and decision-making, and others implement decisions made); professionalism (to make decisions in an organization, the manager must have relevant knowledge, skills, work experience) (Petrunia et al., 2011).

According to the study by M.V. Dzhafarova, to date, the category of "managerial decision" have several meanings, such as: 1) the choice of the activities related to the development of an adequate response of the organization to the impact of any external environmental factor; 2) an option of the manager's impact on the executor of a decision (object managed); 3) an activity in the management subsystem that involves the preparation, finding, choice and adoption of certain options, according to existing circumstances, the interests and needs of the environment; 4) an optional impact of the management subsystem on the managed one; 5) an administrative and practical activity of the manager in the managed system (actions of the lower level manager to implement the decision (commission) of the higher level manager. In addition, the scientist formulates the following general specificities of managerial decisions: a) a managerial decision implies the availability of options and the choice of one, according to objective circumstances, interests and needs; b) the choice and adoption of the option are the result of a conscious mental and psychological activities; c) the need for and substantive content of the managerial decision are determined by and oriented towards the achievement of the objective; d) the managerial decision has a catalytic and organizing power (Dzhafarova, 2008).

The process of managerial decision-making involves the following components:

1. A decision-maker is a person or group of people who have the necessary decision-making power and are responsible for it.

2. Controllable variables are the set of factors and conditions that give rise to a problem, which can be managed by a decision-maker.

3. Uncontrollable variables are situations that may not be managed by a decision-maker, but that may be managed by others. When combined with controllable variables, uncontrollable variables can influence the outcome of the choice, forming the background of the problem or its environment.

4. Constraints (internal and external) on the value of controllable and uncontrollable variables that together define the tolerance range of a decision.

5. Criterion (or criteria) for evaluating alternative decisions. The criterion may be quantitative or qualitative (in terms of individual preferences or in terms of fuzzy logic).

6. A decisive rule (or system of decisive rules) is the principles and methods of decision-making that result in recommendations or a registered decision (although the final choice depends on the decision-maker).

7. Alternatives (possible results) can depend both on the qualitative or quantitative value of the controllable and uncontrollable variables and on the choice itself.

8. The decision can imply at least two alternatives to conduct (otherwise the problem of managerial decision does not arise due to lack of choice).

9. Possibilities exist for implementation of the decision (Bilinska, Kovbasiuk, 2011, pp. 58-59).

Therefore, the managerial decision is the professional performance of the authorized person, aimed at ensuring the efficient functioning of the managed system. We argue that the procedure for applying incentives to local self-government employees is directly related to the consistency of making certain managerial decisions. In this context, we consider it appropriate to identify the following stages and sub-stagesinapplyingincentivesforlocalselfgovernment employees:

1) preparation for a managerial decision This step includes: a) identification of employees and their merits, i. e. the appropriateness of incentives; $b$ ) determination of the amount of funds that are in the bonus fund which can be used to reward; 
c) determination of the amount of the award (for example, the amount of the bonus);

2) the adoption of a managerial decision accompanied by the issuance of an order, that is, its legal form;

3) the implementation of a managerial decision that provides for the direct award (direct accrual and payment of bonuses);

4) control of the implementation of the managerial decision.

The initial impulse of the decision-making process is information about the state of the object managed, that is, identification of the problem situation. The action on the object managed is carried out after the development and adoption of the relevant decision, which in the form of information is submitted to the object managed. Therefore, the managerial decision-making process is cyclical, and its main element is the problem, that is the discrepancy of the actual state of the object managed with the desired or given, with the established objective or the desired result. Developing an action plan to address the problem is the essence of the decision-making process. The problem is always related to the combination of conditions or factors that create the problem situation. That is why the beginning of the decision-making process is the description of the problem situation and the factors that led to it (Morhulets, 2012).

Therefore, the preparation of a managerial decision, according to A.F. Melnyk, combines: the identification of an objective (set of objectives); the collection and analysis of information on the task to be solved; the identification, forecasting of the unfold of the situation and problems; making of options for possible managerial decisions; development of criteria and selection of effective options of managerial decisions (Melnyk et al., 2003, p. 115).

For example, with regard to the preparatory phase, the first point to be made is the need to identify the range of employees and their merits, i. e. the appropriateness of incentives. Thus, local self-government employees are awarded bonuses in accordance with their personal contribution to the overall results of the performance, within the bounds of the bonus fund, formed in the amount of three months' fund for remuneration and savings of the wage fund. They may also be provided with pecuniary assistance to solve social and welfare problems and assistance for convalescence in the amount of the average monthly wage. Bonuses for managers and their deputies, allowances and supplements to their salaries, and pecuniary assistance are provided by the higher-level body's decision, within available funds for remuneration (Yarmysh, Serohin, 2002).
With regard to the sources of funding for incentives, focus should be on para. 2 of part 2 of the Resolution "On streamlining the structure and conditions of remuneration of employees of the staff of executive authorities, prosecutors, courts and other bodies" which states that heads of SGBs shall be entitled to award bonuses to employees in accordance with their personal contribution to overall performance, as well as on public and professional holidays and anniversary dates. Moreover, the above-mentioned bonuses are paid within a bonus fund established in the amount of not less than 10 per cent of the salary and savings of the wage fund. The savings may arise, inter alia, from vacancies, sick leave and unpaid leave, and in other cases (Cabinet of Ministers of Ukraine, 2006).

\section{Bonuses and allowances are awarded to} the staff

Bonuses and allowances are awarded to the staff based on a comprehensive analysis of the performance of basic duties in accordance with the order of the village head, within the funds provided for the bonus. The amount of the bonus for each worker is determined according to his/her personal contribution to the overall results of the village council's activities. Assessment of the personal contribution of employees considers competence, initiative, complexity, quality and speed of the work, its scope, creative and analytical work, efficiency and productivity of developments, decisions taken and other achievements (Cabinet of Ministers of Ukraine, 2006).

It should be noted that the main indicators (conditions) for awarding bonuses to the employees of the Village Council apparatus are: the implementation of the activities envisaged in the Council's work plans; rational and efficient organization of the work of the team and conscientious performance of the job responsibilities; effective managerial decisions, high performance; timeliness and quality of preparation of background and analytical materials for draft legal regulations for consideration at sessions and meetings; closer cooperation with the public, the relevant services of the district, the village, enterprises and entrepreneurs; timely and effective execution of the orders, recommendations of the highest authorities, tasks and commissions assigned by the leadership of the village council; creativity, initiative, professionalism and application of effective working methods; quality and timely preparation of documents; quality and effective processing of citizens' letters and appeals; additional time worked; performance of duties that are not part of the post in accordance with the job description; constant self-improvement, professional development; proper maintenance 
of the workplace, preservation of the property of the village council and its rational and careful use; compliance with labour legislation, labour regulations, labour and financial discipline, occupational safety and health and fire safety.

The next step, as noted above, is the adoption of a managerial decision accompanied by the issuance of an order, that is, its legal form. Decision-making is the part of any management function, as decision-making is the main product of a manager's work. Therefore, understanding the nature of managerial decision-making is essential for a better understanding of the management process in general (Petrunia et al., 2011).

According to O.N. Yevtushenko, managerial decision-making may be intuitive (own feeling that the choice is right); be based on judgment (choice based on knowledge or experience, that is, the manager uses knowledge of what has happened in such situations in the past and chooses such an option, which he believes will be the most successful); be rational (decision is based on an objective analytical process implying the relationship of consecutive stages: diagnosis of problem - formulation of criteria for decision-making decision - identification of alternatives - assessment of alternatives - choice of decision) (Yevtushenko, 2014, p. 49). In addition, the author argues that managerial decision-making requires a high level of competence, time, energy, experience and responsibility on the part of managers. Managerial decision-making is an important part of the management activities around which the life of an organization revolves. Sound and effective managerial decisions by the head affect the success of the organization (Yevtushenko, 2014, p. 49).

Finally, managerial decisions should meet certain requirements: efficiency (to fully contribute to achievement of the organization's objective); cost-effectiveness (to contribute to achievement of the objective set in a cost-effective manner); timeliness (not only in decision-making, but also in achieving an objective); validity (executors of a decision must understand the reasons for making that decision); reality (a decision must not be abstract) (Shcheblykina, Hrybova, 2015). Key ones are validity, clarity of language, real feasibility, timeliness, cost-effectiveness (measured by cost), efficiency (measured by the degree to which objectives are achieved in relation to resource costs) (Shcheblykina, Hrybova, 2015).

Therefore, the adoption of a managerial decision is an important stage in applying incentives to employees of local self-government bodies, since in fact, at this stage the legal form of the respective actions is carried out by issuing an order. B.I. Sazonov proves that an order is a legal document that begins a management cycle, so that an adequate perception of the information in it is important for the entire management organization (Sazonov, 1976, p. 112).

The Incentive Order for local self-government employees must contain the following information: a) the list of persons to whom the incentive is applied; b) grounds for granting the incentives; c) the type of incentives; d) time for which an incentive must be granted; e) in addition, the order must contain all details necessary for the said documents.

Another stage in applying incentives for local self-government employees is the implementation of a managerial decision. The implementation of the managerial decision is directly related to the implementation of the accrual and payment of bonuses of incentives to local self-government employees. For example, the monthly bonus for public officials of a public authority is paid not later than the date of payment of wages for the month in which the bonus is accrued, and the quarterly bonus not later than the date of payment of wages for the last month of the quarter, in which the bonus is accrued.

The final stage, which should be underlined, is the control of the implementation of the relevant managerial decision. Traditionally, control is the process of ensuring that the objectives set are met (Bandurka, 1998). According to Yu.O. Tykhomyrov, control is the verification of compliance with and fulfilment of the tasks, plans and decisions, set according to law, that is, the beginning of a cycle devoted to the evaluation of the ongoing process. In this context, the author emphasizes: first, the functional assignment of control, second, that it arises at a certain stage of the management process, and third, that control is exercised by all public administrators (Tykhomyrov, 1998, p. 58).

As a management function, control is the continuation of planning and regulatory functions and accompanies the implementation of managerial decisions. Control involves identifying and documenting actual indicators (outcomes of decision implementation) and comparing them with indicators planned to measure organizational performance. Control also includes comparing the expected and actual implementation rates of plans, verifying the admissibility of underlying assumptions and control of the methodological and substantive consistency of management implementation plans. Moreover, control includes a set of actions to analyse potential deviations from planned indicators. Comparison and analysis stimulate new decision-making processes, 
which in turn initiate remedial actions and provide long-term learning effects (Trofymova, Trofymov, 2012).

In the context of the topic, it should be noted that the control of applying initiatives has not been sufficiently regulated to date, in particular with regard to its procedure and the actors authorized to carry it out. Control of decision implementation involves the establishment of a control mechanism to detect changes in the external and internal environments in which organizations operate, the location of problems, and the need for additional decisions to achieve the objectives of the system. The control mechanism should consist of two parts: control of changes in the external environment (system input) and internal (in organization and system outputs) (Trofymova, Trofymov, 2012).

\section{Conclusions}

Therefore, the procedure for applying incentives to employees of local self-government bodies has been rather superficially regulated, and the corresponding regulatory provisions are scattered in numerous legal regulations of different legal force, that in turn leads to ambiguous interpretations. The shortcomings of this procedure include:

a) the clear criteria to be taken into account in determining who should be rewarded are absent;

b) the procedure for formation and issuance of the Incentive Order, its content and structure are not sufficiently regulated;

c) the issue of supervising and control the implementation of managerial decisions related to applying incentives to local self-government employees is not regulated.

\section{References:}

Bandurka, O.M. (1998). Upravlinnia v orhanakh vnutrishnikh sprav Ukrainy [Department of Internal Affairs of Ukraine]. Kharkiv: Un-t vnutr. sprav [in Ukrainian].

Bilinska, M.M., Kovbasiuk, Yu.V. (2011). Pryiniattia upravlinskykh rishen: orhanizatsiino-psykholohichnyi aspekt [Managerial decisions: organizational and psychological aspect]. Kyiv: NADU [in Ukrainian].

Cabinet of Ministers of Ukraine (2006). Pro uporiadkuvannia struktury ta umov oplaty pratsi pratsivnykiv aparatu orhaniv vykonavchoi vlady, orhaniv prokuratury, sudiv ta inshykh orhaniv: Postanova Kabinetu Ministriv Ukrainy vid 9 bereznia 2006 roku № 268 ["On streamlining the structure and conditions of remuneration of employees of the staff of executive authorities, prosecutors, courts and other bodies": Resolution of the Cabinet of Ministers of Ukraine from March 9, 2006, № 268]. rada.gov.ua. Retrieved from: https://zakon.rada. gov.ua/go/268-2006-п [in Ukrainian].

Dzhafarova, M.V. (2008). Administratyvni protsedury pryiniattia ta realizatsii upravlinskykh rishen orhaniv vnutrishnikh sprav u vidnosynakh z naselenniam [Administrative procedures for making and implementing managerial decisions of law enforcement agencies in relations with the population]. Candidate's thesis. Kharkiv [in Ukrainian].

Melnyk, A.F., Obolenskyi, O.Yu., Vasina, A.Yu. (2003). Derzhavne upravlinnia [Governance]. Kyiv: Znannia-Pres [in Ukrainian].

Morhulets, O.B. (2012). Menedzhment u sferi posluh [Management in the field of services]. Kyiv: Tsentr uchbovoi literatury [in Ukrainian].

Navrotskyi V.O. (2011). Kryminalne pravo Ukrainy [Criminal law of Ukraine]. Kyiv: Znannia [in Ukrainian].

Petrunia, Yu.Ye., Hovorukha, V.B., Litovchenko, B.V. et al. (2011). Pryiniattia upravlinskykh rishen [Making managerial decisions]. Kyiv: Tsentr uchbovoi literatury [in Ukrainian].

Ruliev, V.A., Hutkevych, S.O. (2011). Menedzhment [Management]. Kyiv: Tsentr uchbovoi literatury [in Ukrainian].

Sazonov, B.I. (1976). Informatsyonnaia systema mynysterstv: soderzhanye y pravovoe rehulyrovanye [Information system of ministries: content and legal regulation]. Sovetskoe hosudarstvo i pravo - Soviet state and law, no. 3, pp. 110-113 [in Russian].

Shcheblykina, I.O., Hrybova, D.V. (2015). Osnovy menedzhmentu [Fundamentals of management]. Melitopol: Melitopolska miska drukarnia [in Ukrainian].

Trofymova, L.A., Trofymov, V.V. (2012). Metody priniatiia upravlencheskikh reshenii [Managerial decision making methods]. St. Petersburg: SPbGUEF [in Russian].

Tykhomyrov, Yu.A. (1998). Kurs admynystratyvnoho prava i protsessa [Administrative Law and Process Course]. Moscow: Izd. h-na Tykhomyrova M.Yu. [in Russian].

Yarmysh, O.N., Serohin, V.O. (2002). Derzhavne budivnytstvo ta mistseve samovriaduvannia v Ukraini [State building and local self-government in Ukraine]. Kharkiv: Nats. un-t vnutr. sprav [in Ukrainian].

Yevtushenko, O.N. (2014). Upravlinski rishennia: sutnist ta kharakterni rysy [Managerial decisions: essence and characteristics]. Naukovi pratsi Chornomorskoho derzhavnoho universytetu imeni Petra Mohyly - Scientific works of Petro Mohyla Black Sea State University, no. 237, pp. 47-51 [in Ukrainian]. 


\section{Петро Мозолевсъкий,}

доктор філософії в галузі права, помічник-консультант народного депутата Украйни, площа Солом'янська, 1, Київ, Україна, індекс 03035, o.s.tarasenko@gmail.com, Petromozolevskyi@ukr.net

ORCID: orcid.org/0000-0002-3524-8868

\section{ПОРЯДОК ЗАСТОСУВАННЯ ЗАОХОЧЕНЬ ДО ПРАЦІВНИКІВ ОРГАНІВ МІСЦЕВОГО САМОВРЯДУВАННЯ}

Анотація. Актуальність статті полягає в тому, що для використання заохочень до працівників органів місцевого самоврядування з дотриманням принципів законності та справедливості важливе їх застосування в певному порядку. Метою статmi є характеристика порядку застосування заохочень до працівників органів місцевого самоврядування та визначення його недоліків. Результати. Встановлено, що управлінське рішення - це професійна діяльність уповноваженої особи, спрямована на те, щоб забезпечити ефективне функціонування керованої системи. Порядок застосування заохочень до працівників органів місцевого самоврядування безпосередньо пов'язаний із послідовністю прийняття певних управлінських рішень. Наголошено на тому, що основними показниками (умовами) для преміювання працівників апарату сільської ради є такі: 1) виконання заходів, передбачених планами роботи органу; 2) раціональна й ефективна організація роботи колективу та добросовісне виконання посадових обов'язків; 3) прийняття ефективних управлінських рішень, висока результативність у роботі; 4) своєчасність і якість підготовки довідкових та аналітичних матеріалів до проєктів нормативно-правових актів для розгляду на сесіях і засіданнях; 5) налагодження тісної співпраці з громадськістю, відповідними службами району, села, з підприємствами, підприємцями; 6) своєчасне й ефективне виконання розпоряджень, рекомендацій вищих органів влади, завдань і доручень, поставлених керівництвом сільської ради; 7) творчість, ініціатива, професійність та використання ефективних методів роботи; 8) якісна та своєчасна підготовка документів; 9) якісна й ефективна робота злистами та зверненнями громадян; 10) додатково відпрацьований час; 11) виконання робіт, які не належать до посадових обов’язків згідно 3 посадовою інструкцією; 12) постійне самовдосконалення, підвищення професійної кваліфікації; 13) належне утримання робочого місця, збереження майна сільської ради та його раціональне й бережливе використання; 14) дотримання вимог трудового законодавства, правил трудового розпорядку, трудової та штатно-фінансової дисципліни, техніки безпеки і пожежної безпеки, охорони праці. Висновки. На сьогодні порядок застосування заохочень до працівників органів місцевого самоврядування врегульований досить поверхнево, а норми права, якими вони регулюються, розпорошені в численних нормативно-правових актах різної юридичної сили, що своєю чергою призводить до неоднозначного їх тлумачення. До недоліків вказаного порядку варто віднести: а) відсутність чітких критеріїв, які необхідно враховувати під час визначення кола осіб, котрі заслуговують на заохочення; б) не досить урегульований порядок формування та видання наказу про заохочення працівників, його зміст і структуру; в) неврегульованість питання здійснення нагляду й контролю за реалізацією управлінських рішень, пов'язаних із застосуванням заохочень до працівників органів місцевого самоврядування.

Ключові слова: управління, контроль, функція, реалізація, документування, показники.

The article was submitted 13.08.2021

The article was revised 03.09.2021

The article was accepted 21.09.2021 